\title{
Detection of penicillin tolerance in streptococci
}

\author{
GRETA J SLATER, DAVID GREENWOOD \\ From the Department of Microbiology and PHLS Laboratory, University Hospital, Queen's Medical Centre, \\ Nottingham NG7 $2 U H$
}

SUMMARY "Tolerance" to penicillin in streptococci was investigated by two different techniques. Of 70 strains examined, 35 appeared tolerant in conventional titrations and 31 appeared tolerant when tested by a recently-described disc method. There was $88 \%$ agreement between the two methods, but the disc test failed to detect tolerance shown by titrations in six strains of streptococci, including three $\beta$-haemolytic strains belonging to Lancefield's group D.

A significant relationship was observed between tolerance and Eagle's optimum dosage effect: $71 \%$ of tolerant strains examined displayed the Eagle effect, whereas only $17 \%$ of non-tolerant strains exhibited the effect.

Bacteria described as "tolerant" to penicillin are inhibited but not killed by penicillin and related antibiotics. ${ }^{1}$ The phenomenon has been demonstrated in several types of streptococci: tolerant mutants of Lancefield group A streptococci have been produced $^{2}$ and tolerant strains of Lancefield groups $\mathrm{B}, \mathrm{C}, \mathrm{D}, \mathrm{G}^{3-6}$ and viridans streptococci ${ }^{7-8}$ have been isolated from cases of human infection.

Tolerance may be associated with failure of penicillin therapy in conditions such as bacterial endocarditis where bactericidal activity is a prerequisite of successful therapy. ${ }^{8}$ Consequently, a simple, reliable test for the detection of tolerance would be useful to enable effective treatment to be instituted more promptly.

Of the tests available for the detection of tolerance, estimation of the ratio between the minimum inhibitory concentration (MIC) and the minimum bactericidal concentration (MBC) is timeconsuming and the penicillin-gradient method of Kim and Anthony ${ }^{4}$ requires the preparation of special plates. Recently, Dankert et al ${ }^{9}$ have described a disc method which appears to offer the possibility of detecting tolerance in streptococci very simply on ordinary culture media. We have evaluated this new method with various types of streptococci and have compared the results with $\mathrm{MBC} / \mathrm{MIC}$ ratio estimations. Because Eagle's optimum dosage effect (in which high concentrations of penicillin may achieve less killing than lower concentrations) ${ }^{10}$ may complicate the detection of tolerance, we have also tested for this effect among our strains.

Accepted for publication 3 August 1983

\section{Material and methods}

\section{BACTERIAL STRAINS}

Seventy strains of streptococci were examined: 16 Lancefield group A; 14 Lancefield group B; 18 Lancefield group D (of which 11 were nonhaemolytic); 2 Lancefield group G; 11 Strep pneumoniae; and nine viridans streptococci. All strains were isolated from clinical specimens in the Public Health Laboratory, Queen's Medical Centre, Nottingham.

\section{MIC/MBC TITRATIONS}

Serial doubling dilutions of benzylpenicillin ('Crystapen'; Glaxo Research Laboratories) were prepared in $1 \mathrm{ml}$ volumes of Todd-Hewitt broth (Oxoid Ltd), supplemented with $1 \%$ neopeptone (Difco Laboratories Inc) for the growth of Strep pneumoniae. Tubes were inoculated from diluted overnight broth cultures to acheive an inoculum of approximately $2 \times 10^{5}$ colony-forming units $(\mathrm{CFU}) / \mathrm{ml}$. After overnight incubation at $37^{\circ} \mathrm{C}$, the MIC was read as the lowest concentration of penicillin at which no turbidity was visible. For the estimation of the MBC, one drop of a 1/10 dilution of $\beta$-lactamase (ex Bacillus cereus; Genzyme Biochemicals Ltd, Maidstone, Kent) was added to each tube showing no growth, the tube was shaken and $0.1 \mathrm{ml}$ was removed and spread on a blood agar plate. Bactericidal activity was indicated by the development of less than 20 colonies after overnight incubation that is, $99.9 \%$ killing). 


\section{DISC TEST FOR TOLERANCE}

The method was based on that described by Dankert et al. ${ }^{9}$ Overnight broth cultures of streptococci were diluted $1 / 10$ with fresh broth and $0.1 \mathrm{ml}$ was spread on a blood agar plate. A two-unit penicillin disc was placed on the inoculum. For those streptococci of which the MIC of penicillin was $2 \mu \mathrm{g} / \mathrm{ml}$ or more, a $10 \mu \mathrm{g}$ ampicillin disc was used. Plates were incubated overnight at $37^{\circ} \mathrm{C}$. The diameter of the zone of inhibition was measured and the antibiotic discs were replaced by discs containing $\beta$-lactamase (see below). After a further $24 \mathrm{~h}$ incubation, the number of colonies developing inside the inhibition zone was counted. $\beta$-lactamase discs were prepared as follows: $7 \mathrm{~mm}$ diameter discs of photoprint drying paper were cut with a hole punch and sterilised by autoclaving for $5 \mathrm{~min}$ at $136^{\circ} \mathrm{C}$. $\beta$-lactamase $(0.05 \mathrm{ml})$ was pipetted onto each disc and allowed to dry. The discs were used immediately.

\section{VIABLE COUNTING}

To test for the Eagle effect ${ }^{10} 55$ strains were examined by a viable counting method. Tubes containing $20 \mathrm{ml}$ of broth were inoculated from overnight broth cultures to achieve an inoculum of approximately $10^{5}$ to $10^{6} \mathrm{CFU} / \mathrm{ml}$. The tubes were incubated in a 12-channel turbidity monitoring device. ${ }^{11}$ When bacterial growth had raised the opacity to a level of $30 \%$ of maximum, benzylpenicillin was added to achieve concentrations equivalent to 2 , 10 and 50 times the previously estimated MIC. Viable counting was carried out by the agar drop method"12 by use of the Colworth "Droplette" device (AJ Seward, London). Quintuplicate counts were performed before adding the penicillin and at intervals during the next six hours.

\section{Results}

The criterion of tolerance for the titration method was an MBC/MIC ratio of 32 or more. ${ }^{19}$ Using the disc method, growth of 10 or more colonies within the penicillin inhibition zone provided the best correlation with the titration method and this was taken as the cut-off point for tolerance. The results obtained by the two methods are summarised in Tables 1 and 2. None of the Strep pneumoniae strains exhibited tolerance by either method and tolerance was detected in only two of the Strep pyogenes (Lancefield group A) strains: one by each method. Of the remaining 43 strains of streptococci, 34 displayed tolerance in MIC/MBC titrations and 30 were considered tolerant by the disc test.

The methods were in agreement for 62 of the 70 strains tested ( $88 \%$ agreement). The disc method failed to detect tolerance shown by titrations in six of 35 strains $(17 \cdot 1 \%$ false negative) and tolerance was indicated by the disc test in two of 35 strains which did not show the effect in titration $(6.25 \%$ false positive). Three of the six "false negative' results occurred with $\beta$-haemolytic streptococc belonging to Lancefield's group D (Table 3 ).

Viable counts were performed on 55 strains (31 tolerant; 24 non-tolerant, as judged by titration) in

Table 1 Range of MICs and MBCs observed in titrations of benzylpenicillin with 70 strains of streptococci

\begin{tabular}{|c|c|c|c|c|c|}
\hline Organism & $\begin{array}{l}\text { No of } \\
\text { strains }\end{array}$ & $\begin{array}{l}\text { Range of } M I C \\
(\mu g / m l)\end{array}$ & $\begin{array}{l}\text { Range of } M B C \\
(\mu g / m l)\end{array}$ & $\begin{array}{l}\text { Range of } \\
M B C I M I C \\
\text { ratio }\end{array}$ & $\begin{array}{l}\text { Number with } \\
M B C / M I C \\
\text { ratio } \geqslant 32\end{array}$ \\
\hline $\begin{array}{l}\text { Strep pneumoniae } \\
\text { Lancefield group A } \\
\text { Lancefield group B } \\
\text { Lancefield group D (haemolytic) } \\
\text { Lancefield group D (non-haemolytic) } \\
\text { Lancefield group G } \\
\text { Viridans streptococci }\end{array}$ & $\begin{array}{r}11 \\
16 \\
14 \\
7 \\
11 \\
2 \\
9\end{array}$ & $\begin{array}{l}0.008-0.032 \\
0.008-0.016 \\
0.064 \\
0.064-4 \\
2-32 \\
0.016-0.032 \\
0.032-1\end{array}$ & $\begin{array}{c}0 \cdot 032-0 \cdot 064 \\
0 \cdot 016-1 \\
0 \cdot 064->8 \\
0 \cdot 5->256 \\
>64->4000 \\
1->2 \\
0 \cdot 064->8\end{array}$ & $\begin{array}{c}1-8 \\
1-64 \\
1->128 \\
8->64 \\
>32->64 \\
64->64 \\
1->256\end{array}$ & $\begin{array}{r}0 \\
1 \\
10 \\
6 \\
11 \\
2 \\
5\end{array}$ \\
\hline
\end{tabular}

Table 2 Detection of penicillin tolerance in 70 strains of streptococci using the disc method (see methods)

\begin{tabular}{|c|c|c|c|c|}
\hline \multirow[t]{2}{*}{ Organism } & \multicolumn{4}{|c|}{ No of strains with the indicated No of colonies within the inhibition zone } \\
\hline & \multicolumn{2}{|c|}{ (Non-tolerant) } & $10-99$ & $\geqslant 100$ \\
\hline $\begin{array}{l}\text { Strep preumoniae } \\
\text { Lancefield group A } \\
\text { Lancefield group B } \\
\text { Lancefield group D (haemolytic) } \\
\text { Lancefield group D (non-haemolytic) } \\
\text { Lancefield group G } \\
\text { Viridans streptococci }\end{array}$ & $\begin{array}{r}11 \\
11 \\
3 \\
4 \\
0 \\
0 \\
4\end{array}$ & $\begin{array}{l}0 \\
4 \\
0 \\
0 \\
1 \\
1 \\
0\end{array}$ & $\begin{array}{l}0 \\
1 \\
5 \\
1 \\
8 \\
1 \\
0\end{array}$ & $\begin{array}{l}0 \\
0 \\
6 \\
2 \\
2 \\
0 \\
5\end{array}$ \\
\hline
\end{tabular}


Table 3 Performance of the disc test compared with the titration method

\begin{tabular}{|c|c|c|c|c|}
\hline \multicolumn{2}{|l|}{ Organism (No of strains) } & \multicolumn{2}{|c|}{ No in which the disc test was } & \multirow{2}{*}{$\begin{array}{l}\text { Percentage } \\
\text { agreement }\end{array}$} \\
\hline & & False-positive & False-negative & \\
\hline $\begin{array}{l}\text { Strep pneumoniae } \\
\text { Lancefield group A } \\
\text { Lancefield group B } \\
\text { Lancefield group D (haemolytic) } \\
\text { Lancefield group D (non-haemolytic) } \\
\text { Lancefield group G } \\
\text { Viridans streptococci }\end{array}$ & $\begin{array}{r}(11) \\
16) \\
(14) \\
(7) \\
\left(\begin{array}{l}11 \\
(2) \\
(9)\end{array}\right.\end{array}$ & $\begin{array}{l}0 \\
1 \\
1 \\
0 \\
0 \\
0 \\
0\end{array}$ & $\begin{array}{l}0 \\
1 \\
0 \\
3 \\
1 \\
1 \\
0\end{array}$ & $\begin{array}{l}100 \\
87 \cdot 5 \\
92 \cdot 9 \\
57 \cdot 2 \\
90 \cdot 9 \\
50 \\
100\end{array}$ \\
\hline
\end{tabular}

Table 4 Relationship between tolerance and the Eagle phenomenon

\begin{tabular}{|c|c|c|c|c|c|}
\hline \multirow{2}{*}{\multicolumn{2}{|c|}{ Organism (No of strains) }} & \multicolumn{2}{|l|}{ Tolerant } & \multicolumn{2}{|c|}{ Non-tolerant } \\
\hline & & Eagle +ve & Eagle-ve & Eagle +ve & Eagle-ve \\
\hline $\begin{array}{l}\text { Strep pneumoniae } \\
\text { Lancefield group A } \\
\text { Lancefield group B } \\
\text { Lancefield group D (haemolytic) } \\
\text { Lancefield group D (non-haemolytic) } \\
\text { Lancefield group G } \\
\text { Viridans streptococci } \\
\text { Total (55) }\end{array}$ & $\begin{array}{r}(11) \\
10) \\
14 \\
(7) \\
(10) \\
(2) \\
(1)\end{array}$ & $\begin{array}{r}0 \\
1 \\
7 \\
4 \\
9 \\
0 \\
1 \\
22\end{array}$ & $\begin{array}{l}0 \\
0 \\
4 \\
2 \\
1 \\
2 \\
0 \\
9\end{array}$ & $\begin{array}{l}0 \\
2 \\
1 \\
1 \\
0 \\
0 \\
0 \\
4\end{array}$ & $\begin{array}{r}11 \\
7 \\
2 \\
0 \\
0 \\
0 \\
0 \\
20\end{array}$ \\
\hline
\end{tabular}

order to test for Eagle's optimum dosage effect. The Eagle phenomenon was observed in $22(71 \%)$ of the tolerant strains and in $4(17 \%)$ of the non-tolerant strains. The difference was statistically significant ( $p$ $=<0.001 ; \chi^{2}$ test with Yates' correction).

\section{Discussion}

There is increasing evidence that penicillin tolerance in Gram-positive cocci is a common phenomenon. ${ }^{13-15}$ There is also evidence that penicillin tolerance may be associated with treatment failure, particularly in endocarditis. ${ }^{16-18}$

In the present study $50 \%$ of streptococci tested exhibited tolerance as judged by an $\mathrm{MBC} / \mathrm{MIC}$ ratio of 32 or more and the phenomenon was common to all streptococci tested except Strep pneumoniae. The simple disc test of Dankert et al ${ }^{9}$ appears to offer a reasonably reliable method of screening for tolerance among most species of streptococci and like Dankert et al ${ }^{9}$ we found no discrepancies among viridans streptococci, a group commonly incriminated in endocarditis. However, three of six $\beta$-haemolytic streptococci belonging to Lancefield's group $\mathrm{D}$ which were shown to be tolerant in $\mathrm{MIC} /$ MBC titrations were not detected by the disc test. This large discrepancy was not experienced with non-haemolytic group D streptococci and the number of haemolytic group D strains tested was small. Nevertheless, these results suggest that the screening method may not be reliable for some group D strains.
As discussed elsewhere ${ }^{19}$ the Eagle phenomenon ${ }^{10}$ may cause difficulties in the detection of tolerance, since, with strains exhibiting this effect, concentrations of antibiotic just above the MIC may achieve 99.9\% killing while higher concentrations fail to meet the criterion of bactericidal activity. We did not encounter this difficulty with the strains we examined. Although 26 of 55 strains tested by the viable counting method displayed the Eagle effect, the action of penicillin on tolerant strains did not achieve the $99.9 \%$ killing criterion of bactericidal activity at any concentration, even when the Eagle effect was present. However, a significant relationship between tolerance and the Eagle phenomenon was revealed: of 31 tolerant strains, $71 \%$ also showed the Eagle effect, whereas only $17 \%$ of 24 non-tolerant strains exhibited the effect.

This positive association may indicate that the optimum dosage effect and tolerance are biochemically related phenomena. The nature of the Eagle phenomenon is not understood, but the basis of the effect possibly lies in the multiple binding sites for penicillin that exist within the bacterial envelope. ${ }^{20}$ It is postulated that inhibition of a very sensitive enzyme by low concentrations of penicillin leads to death of the cell through an autolytic mechanism, ${ }^{21}$ while in the presence of higher penicillin concentrations other enzymes are inhibited, causing bacteristasis and hence antagonism of the bactericidal effect. ${ }^{19}$ Such evidence as is available suggests that tolerance is also related to defective or incomplete autolytic activity, ${ }^{1}$ so that the biochemical relatedness of the two phenomena is certainly possible. 


\section{References}

' Sabath LD, Wheeler N, Laverdiere M, Blazevic D, Wilkinson BJ. A new type of penicillin resistance of Staphylococcus aureus. Lancet 1977; i:443-7.

${ }^{2}$ Gutmann L, Tomasz A. Penicillin resistant and penicillin tolerant mutants of group A streptococci. Antimicrob Agents Chemother 1982;22:128-36.

${ }^{3} \mathrm{Kim}$ KS, Anthony BF. Penicillin tolerance in group B streptococci isolated from infected neonates. J Infect Dis 1981;144:411-9.

${ }^{4} \mathrm{Kim}$ KS, Anthony BF. A method for demonstrating penicillin tolerance in streptococci of groups B and D. In: Holm SE, Christensen P, eds. Basic concepts of streptococci and streptococcal disease. Chertsey: Reedbooks Ltd, 1981:278-9.

s Portnoy, D, Prentis J, Richards GK. Penicillin tolerance of human isolates of group C streptococci. Antimicrob Agents Chemother 1981;20:235-8.

- Noble JT, Tyburski MB, Berman M, Greenspan J, Tenenbaum MJ. Antimicrobial tolerance in group G streptococci. Lancet 1980;ii:982.

${ }^{7}$ Horne D, Tomasz A. Tolerant response of Streptoccocus sanguis to beta-lactams and other cell wall inhibitors. Antimicrob Agents Chemother 1977;11:888-96.

${ }^{8}$ Anderson AW, Cruikshank JG. Endocarditis due to viridans type streptococci tolerant to beta-lactam antibiotics: therapeutic problems. Br Med J 1982;285:854.

' Dankert J, Holloway Y, Joldersma W, Hess J. Screening for penicillin tolerance in viridans streptococci by a simple disk method. J Clin Microbiol 1982;16:744-6.

${ }^{10}$ Eagle H, Musselman AD. Rate of bactericidal action of penicillin in vitro as a function of its concentration and its paradoxically reduced activity at high concentrations against certain organisms. J Exp Med 1948;88:99-131.

" Mackintosh IP, O'Grady F, Greenwood D, Watson BW, Crichton TC, Piper R, Ferrer A. A twelve channel bacterial growth monitoring system. Biomed Eng 1973;8:514-5 and 526.

12 Sharpe AN, Kilsby DC. A rapid, inexpensive bacterial counting technique using agar droplets. J Appl Bacteriol 1971;34:43540.

${ }^{13}$ Bradley HE, Weldy PL, Hodes DS. Tolerance in Staphylococcus aureus. Lancet 1979; 150.

14 Bradley JJ, Mayhall CG, Daiton HP. Incidence and characteris tics of antibiotic-tolerant strains of Staphylococcus aureus Antimicrob Agents Chemother 1978;13:1052-7.

is Holloway Y, Dankert J, Hess J. Penicillin tolerance and bacteria endocarditis. Lancet 1980; 589.

${ }^{16}$ Rajashekaraiah KR, Rice T, Rao VS, Marsh D, Ramakrishna B Kallick CA. Clinical significance of tolerant strains ofs Staphylococcus aureus in patients with endocarditis. AnnIntern Med 1980;93:796-801.

${ }^{17}$ McDonald M, Miles H, Hart D, Stoneberg N. Penicillin tolerancein Streptococcus faecalis. Lancet 1980; ii:321.

18 Brennan RO, Durack DT. Therapeutic significance of penicillin tolerance in experimental streptococcal endocarditis Antimicrob Agents Chemother 1983;23:273-7.

${ }^{19}$ Greenwood D. Antibiotics of the beta-lactam group. Chichester: Research Studies Press, 1982.

${ }^{20}$ Blumberg PM, Strominger JL. Interaction of penicillin with thebacterial cell: penicillin-binding proteins and penicillin $\omega$ sensitive enzymes. Bacteriol Rev 1974;38:291-335.

${ }^{21}$ Tomasz A. The mechanism of the irreversible antimicrobiap effects of penicillins: how the beta-lactam antibiotics kill and lyse bacteria. Ann Rev Microbiol 1979;33:113-7.

Requests for reprints to: Dr David Greenwood, Department of Microbiology, University Hospital, Queen's MeQ $-\infty$ cal Centre, Nottingham NG7 2UH, England. 